\title{
Cilazapril Anhydrous
}

National Cancer Institute

\section{Source}

National Cancer Institute. Cilazapril Anhydrous. NCI Thesaurus. Code C76134.

The anhydrous form of the pyridazine angiotensin-converting enzyme (ACE) inhibitor cilazapril with antihypertensive activity. As a prodrug cilazapril is rapidly metabolized in the liver to cilazaprilat; cilazaprilat competitively binds to and inhibits ACE, thereby blocking the conversion of angiotensin I to angiotensin II. This prevents the potent vasoconstrictive actions of angiotensin II, resulting in vasodilation. Cilazaprilat also decreases angiotensin II-induced aldosterone secretion by the adrenal cortex, which leads to an increase in sodium excretion and subsequently increases water outflow. 